\title{
Flood Hazard Assessment of Residential Areas Outside the Protected Area of the Red River Dike System in Hanoi, Vietnam
}

\author{
Sai Hong ANH ${ }^{1,3}$, Toshinori TABATA ${ }^{2 *}$, Kazuaki HIRAMATSU ${ }^{2}$ and \\ Masayoshi HARADA ${ }^{2}$ \\ ${ }^{1}$ Department of Agro-environmental Sciences, Graduate School of Bioresource and Bioenvironmental \\ Sciences, Kyushu University, Fukuoka, Japan \\ ${ }^{2}$ Department of Agro-environmental Sciences, Faculty of Agriculture, Kyushu University, Fukuoka, \\ Japan \\ ${ }^{3}$ Division for Water Resources Planning for the North Region, Institute of Water Resources Planning, \\ Hanoi, Vietnam
}

\begin{abstract}
Hanoi, the capital city of Vietnam, is highly vulnerable to flooding from the Red River. A flood disaster in 1971 devastated the river basin and claimed the lives of 100,000 people. The Red River dike system was built to protect Hanoi from flooding of the Red River; however, thousands of households are outside the protected area inside the dike system and are highly vulnerable to flooding. Hanoi's flood protection measures are classified according to the water level of the Red River at Long Bien station: warning levels 1,2 , and 3 correspond to water levels of $9.5 \mathrm{~m}, 10.5 \mathrm{~m}$, and $11.5 \mathrm{~m}$, respectively. However, risk-reduction strategies for residential areas based on a flood hazard assessment are still inadequate. This study modeled floods and mapped them using a two-dimensional depth-averaged hydrodynamic model to show the inundation depth levels for the entire area in high resolution. Residential areas were found to be highly vulnerable to flooding at all warning levels. Outside the area protected by the dike system, $40.17 \%\left(15.94 \mathrm{~km}^{2}\right), 54.08 \%\left(21.44 \mathrm{~km}^{2}\right)$, and $79.75 \%$ $\left(31.60 \mathrm{~km}^{2}\right)$ of the study area were inundated at warning levels 1,2 , and 3 , respectively, and these areas contain a small number of households. These results can be used to develop flood prevention and mitigation plans for Hanoi.
\end{abstract}

Discipline: Agricultural Engineering

Additional key words: flood risk management, inundation depth level, two-dimensional hydrodynamic model

\section{Introduction}

Floods are the most frequent natural disaster in the world and cause enormous damage to economies and people. Floods and storms associated with massive rainfall events accounted for $87 \%$ of all extreme weather disasters around the world from 1900 to 2013 (Shadmehri et al. 2019), and the danger of floods and their terrible consequences is well documented. In 2011, as many as 13 million people and more than 6 million ha of land in 66 of Thailand's 77 provinces were affected by flooding (Royal Thai Government and the World Bank 2012). In 2010, Pakistan also suffered from floods (Kirsch et al. 2012). Further, floods are also the most common natural disaster in Europe and have considerably affected human health through drowning, trauma, and increased incidence of mental disorders (Hajat et al. 2005). In 1953, a flood occurred in the Netherlands, low-lying delta-type region, and resulted in 1836 casualties, the deaths of tens of thousands of livestock, and the evacuation of 100,000 people. The damage to buildings, dikes, and other infrastructure was enormous (Gerritsen 2005). In recent decades, the influence of climate change has become more severe and has increased the frequency of floods (Shadmehri et al. 2019). Accelerated climate change is the primary driver for the increasing number of floods around the world as well (Domeneghetti et al. 2015, Tanoue et al. 2016), and flood risk management has 
become more critical than ever. Estimating the vulnerability of areas is indispensable to flood risk management, especially for urban areas that face greater risk and frequency of flooding (Chen et al. 2019). Owing to increasing urbanization and climate change, identifying vulnerable areas is becoming more challenging and ever more urgent, even in high-income countries. The influence of flooding is especially harmful in low-income countries because they have little flood protection (Manfreda et al. 2014, Tanoue et al. 2016). Identifying floodplains and other hazardous areas are a fundamental element of risk mitigation strategy, and many countries have required flood hazard risk mapping by law, like the United States in 1973 and the European Commission in 2007 (Degiorgis et al. 2012). Many studies have utilized such mapping as an essential part of a viable flood risk management strategy (Haile et al. 2018, Darabi et al. 2019, Saksena et al. 2019, Li et al. 2019, Shadmehri et al. 2019).

As shown in Figure 1, the capital city of Hanoi $\left(20^{\circ} 30^{\prime}-21^{\circ} 13^{\prime} \mathrm{N}, 105^{\circ} 30^{\prime}-106^{\circ} 3^{\prime} \mathrm{E}\right)$ is located on the Red River delta in Vietnam and has been heavily influenced by climate change (JICA 2015). In recent decades, many heavy rains and serious flooding have caused severe loss to millions of people, dikes, homes, and possessions.
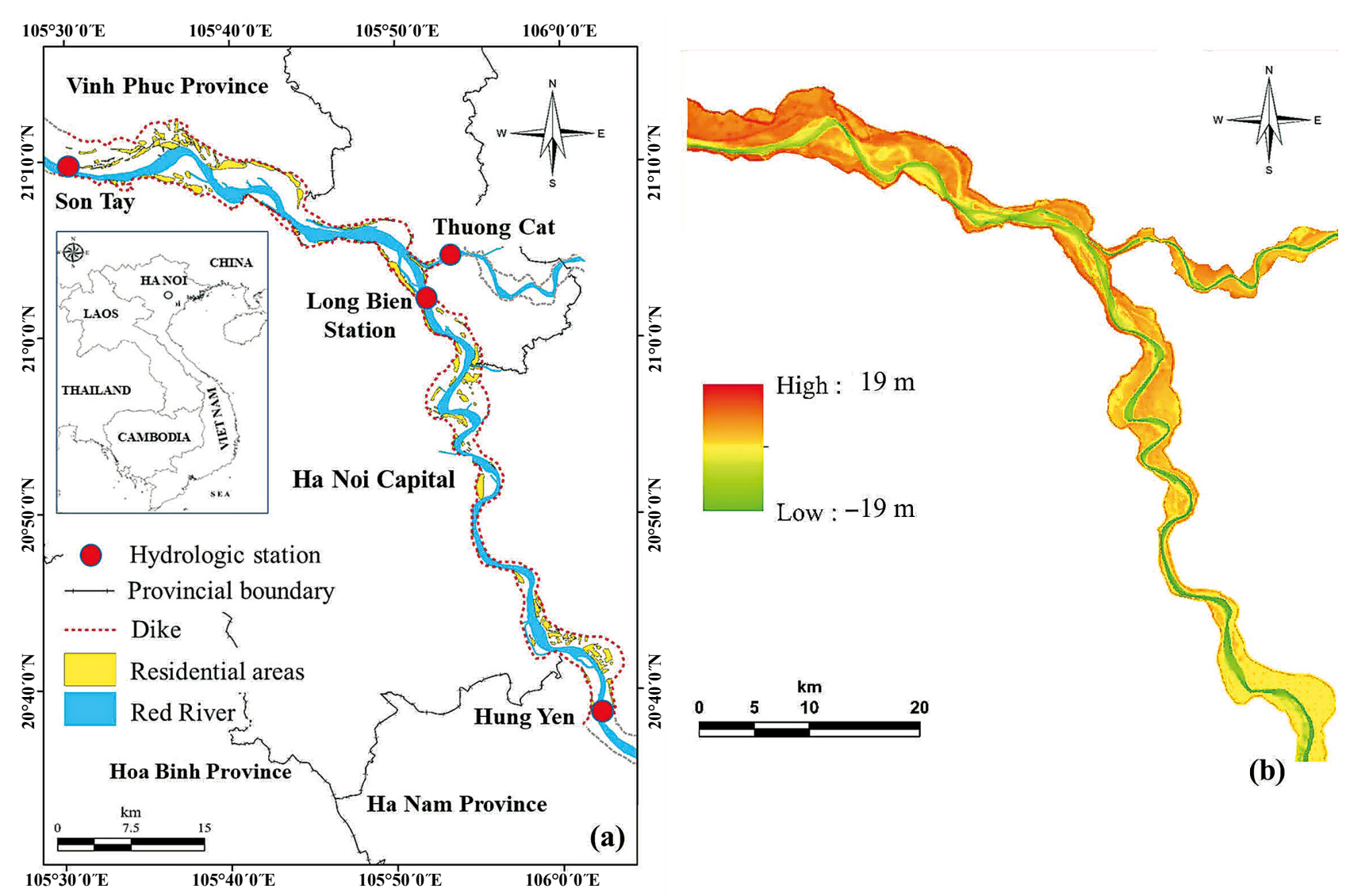

In 1971, the worst-ever flood in the river basin claimed the lives of 100,000 people when the water level of the Red River increased rapidly (NOAA 1993, Vietnamese Government 2005).

Flood risk management in Hanoi faces many challenges, especially because of rapid urbanization and economic development (MONRE 2012, Vietnamese Government 2005). The Red River dike system was built to protect Hanoi from flooding, but thousands of households inside the dike system are still outside the protected area. They remain vulnerable to flooding. Flood protection in Hanoi is classified according to the water level at the Long Bien flood warning station: warning levels 1,2 , and 3 correspond to water levels of $9.5 \mathrm{~m}, 10.5 \mathrm{~m}$, and $11.5 \mathrm{~m}$, respectively. Identifying vulnerable areas is necessary to manage flood risk for residential areas, but the flood risk levels have not yet been comprehensively evaluated. A flood hazard map needs to be developed to improve flood risk planning and to avoid construction without adequate flood protection.

The aim of this study is to identify the residential system that would be inundated at warning levels 1-3 and to improve flood risk management. To this end, a twodimensional depth-averaged hydrodynamic model was areas outside the protected area of the Red River dike

Fig. 1. Location of the study area (a) and elevation map (b) 
constructed to simulate the inundated residential areas, and the latest digital elevation model (DEM) was used for the first time to identify their vulnerability. The model was validated using observed data for the Red River.

\section{Materials and methods}

\section{Study area}

This study focuses on the part of the Red River delta that runs through Hanoi from the Son Tay station to the Hung Yen station, as shown in Figure 1. It covers an area of $364 \mathrm{~km}^{2}$ and is outside the protected area of the Red River dike system, which protects approximately $110 \mathrm{~km}$ of the land adjoining the Red River. This area is characterized by a complex topography that includes the river and residential areas. Topography plays a vital role in numerical simulations of flood risk levels. Recent research on hydraulic modeling has revealed that the Shuttle Radar Topographic Mission (SRTM) Digital Elevation Model (DEM) is the most popular topographic data because of its high vertical accuracy and resolution of $90 \mathrm{~m}$ (Wilson et al. 2007, Neal et al. 2012, Rexer \& Hirt 2014, Sampson et al. 2015, Chaieb et al. 2016, Komi et al. 2017, Chen et al. 2018). In this study, more than 145,000 cells were modeled that utilized a $50 \mathrm{~m}$ resolution DEM for each grid cell. The DEM data were surveyed from 2011 to 2014 and provided by the Institute of Water Resources Planning, Ministry of Agriculture and Rural Development, Vietnam. In order to protect residential areas outside the dike system from flooding by the Red River, the local government of Hanoi utilizes measures determined according to the warning level at Long Bien station, which is based on the river water level (i.e., $9.5 \mathrm{~m}$, $10.5 \mathrm{~m}$, and $11.5 \mathrm{~m}$ corresponding to warning levels 1,2 , and 3 respectively).

\section{Hydrodynamic model}

The inundation of residential areas can be simulated using a three-dimensional numerical model. However, three-dimensional models are time-consuming to run for a large study area. The study area includes the river and a vast floodplain, so the horizontal velocities of the floods are far greater than the vertical velocities. In addition, the flow behavior on a floodplain is often simulated with a two-dimensional depth-averaged model (Dutta et al. 2007, Gharbi et al. 2016, Bates et al. 1999, Bellos et al. 2015). Therefore, a two-dimensional hydrodynamic model was built for this study to identify the inundated residential areas outside the protected area of the Red River dike system. The shallow water equations used in this study are described in detail below.
Continuity equation:

$$
\frac{\partial \eta}{\partial t}+\frac{\partial}{\partial x}\{U(h+\eta)\}+\frac{\partial}{\partial y}\{V(h+\eta)\}=0
$$

Momentum equations in the $x$ and $y$ directions:

$$
\begin{aligned}
& \frac{\partial U}{\partial t}+U \frac{\partial U}{\partial x}+V \frac{\partial U}{\partial y} \\
& =f V-g \frac{\partial \eta}{\partial x}+v_{h}\left(\frac{\partial^{2} U}{\partial x^{2}}+\frac{\partial^{2} U}{\partial^{2} y}\right)-\frac{g n^{2} U \sqrt{U^{2}+V^{2}}}{(h+\eta)^{\frac{4}{3}}} \\
& \frac{\partial V}{\partial t}+U \frac{\partial V}{\partial x}+V \frac{\partial V}{\partial y} \\
& =-f U-g \frac{\partial \eta}{\partial y}+v_{h}\left(\frac{\partial^{2} V}{\partial x^{2}}+\frac{\partial^{2} V}{\partial^{2} y}\right)-\frac{g n^{2} V \sqrt{U^{2}+V^{2}}}{(h+\eta)^{\frac{4}{3}}}
\end{aligned}
$$

where $U$ and $V$ are the depth-averaged horizontal velocity components $(\mathrm{m} / \mathrm{s})$ in the $x$ and $y$ directions, respectively; $\eta$ is the river water level (m); $t$ is the time (s); $h$ is the bottom elevation (m) as shown in Figure $2 ; f$ is the Coriolis parameter $(1 / \mathrm{s}) ; g$ is the gravitational acceleration $\left(\mathrm{m} / \mathrm{s}^{2}\right) ; n$ is Manning's coefficient of roughness $\left(\mathrm{s} / \mathrm{m}^{1 / 3}\right)$; and $v_{h}$ is the coefficient of the eddy viscosity $\left(\mathrm{m}^{2} / \mathrm{s}\right)$.

The coefficient of the eddy viscosity, $v_{h}$, was calculated with the Smagorinsky model (Smagorinsky 1963):

$$
v_{h}=\frac{1}{2} S_{m} A_{G}\left\{\left(\frac{\partial U}{\partial x}\right)^{2}+\frac{1}{2}\left(\frac{\partial V}{\partial x}+\frac{\partial U}{\partial y}\right)+\left(\frac{\partial V}{\partial y}\right)^{2}\right\}^{\frac{1}{2}}
$$

where $S_{m}$ is the Smagorinsky coefficient and $A_{G}$ is the area of each mesh $\left(\mathrm{m}^{2}\right)$.

Uchiyama's wetting-and-drying scheme (Uchiyama 2004) was used to identify the wet and dry areas for each time step. The leapfrog finite difference method was

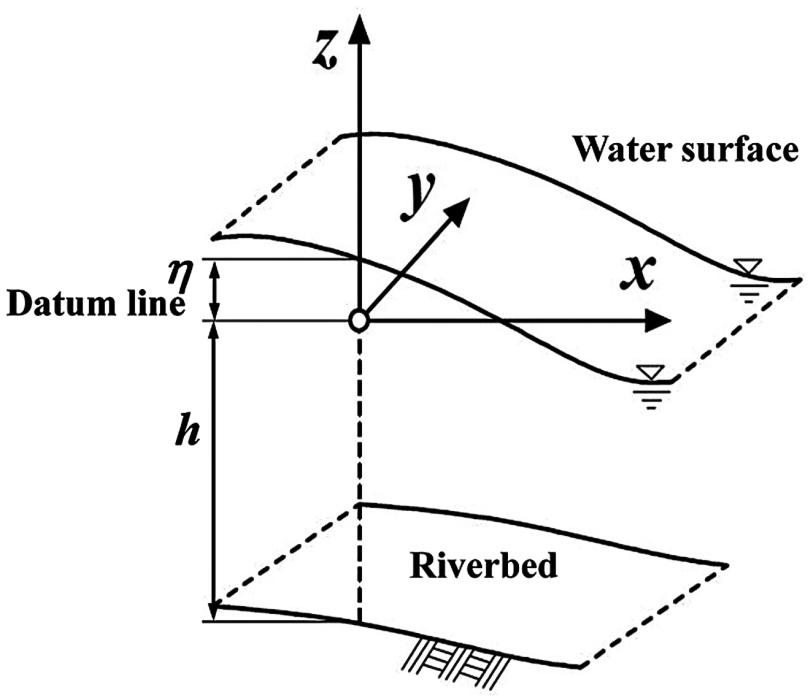

Fig. 2. The coordinate system explanation 
applied to calculate the governing equations on the staggered mesh system.

\section{Boundary conditions and model parameters}

To validate the model, observed data collected in 2013 and 2014 in the Red River area by the Institute of Water Resources Planning, Vietnam were used. The water levels at the Son Tay, Thuong Cat, and Hung Yen stations were used as input boundary conditions. Then the observed water level at the Long Bien station was used to compare the calculated profiles. Three big floods occurred in the Red River delta between 1961 and 2010 (1969, 1971, and 1996), in which water levels at the Long Bien Station reached warning level 3. However, there is insufficient elevation, water level, and discharge data for the 1969 flood. There is also no recorded data for the 1971 flood. The 1996 flood is well-suited to the purpose of this study, so the observed river water level for August 8-31, 1996 was used in the simulation. In August 1996, a massive flood occurred in the Red River delta in Hanoi. Heavy rainfall upstream of the city caused severe inundation in the delta and the city itself, especially in the residential areas outside the dike system. The water level at the peak of this flood event was more than $12.4 \mathrm{~m}$ at Long Bien, which is higher than warning level $3(11.5 \mathrm{~m})$. It had a return period of 22 years based on the discharge statistics from 1961 to 2010 at Son Tay station.

The parameters used in this study are defined as follows: $\Delta t=2.0 \mathrm{~s}, \Delta x=\Delta y=50 \mathrm{~m}, S_{m}=0.2, A_{G}=\Delta x \times \Delta y$ $=2,500 \mathrm{~m}^{2}, f=5.25 \times 10^{-5} \mathrm{~s}^{-1}$, and $g=9.8 \mathrm{~m} / \mathrm{s}^{2}$. Manning's coefficient of roughness, $n$, for each grid element was set to $n=0.025-0.172 \mathrm{~s} / \mathrm{m}^{1 / 3}$ depending on the vegetation, obstructions, and residential area (Bricker et al. 2015, Brunner 2010). Using ArcGIS, we identified the residential, river, and cultivated areas based on map data provided by the Institute of Water Resources Planning of the Ministry of Agriculture and Rural Development, Vietnam. The values of $n$ for the channel, cultivated, and residential areas were defined as $0.025 \mathrm{~s} / \mathrm{m}^{1 / 3}, 0.035$ $\mathrm{s} / \mathrm{m}^{1 / 3}$, and $0.172 \mathrm{~s} / \mathrm{m}^{1 / 3}$, respectively.

\section{Results and discussion}

\section{Model validation}

The model was validated using the observed water level at Long Bien Station. Validation was conducted over three periods from February $2^{\text {nd }}$ to February $10^{\text {th }}$, 2013; July $28^{\text {th }}$ to August $8^{\text {th }}, 2013$; and January $10^{\text {th }}$ to January $21^{\text {st }}, 2014$. The root-mean-square error (RMSE) and Nash-Sutcliffe model efficiency (NS) were calculated to show the accuracy of the model, as shown in Figure 3. In 2013, the calculated RMSE values were only $0.08 \mathrm{~m}$ and $0.14 \mathrm{~m}$ for both periods, and the NS values were very high at 0.96 and 0.97 , respectively. In 2014, the model results also showed good agreement with the observed data, with an RMSE of $0.05 \mathrm{~m}$ and an NS value of 0.99 . The validation results confirmed the accuracy of the two-dimensional hydrodynamic model developed for this study.

\section{Total inundated residential areas}

Figure 4 shows the calculated and observed water levels at Long Bien station for August 8-31, 1996, and the times when the calculated water level reached warning levels 1, 2, and 3. Figure 5 lists the inundated residential areas at warning levels 1,2 , and 3. At warning level 1, $40.17 \%$ of the residential areas outside the protected area of the Red River dike system were flooded. At warning level 2, 54.08\% were also flooded. At warning level 3, $79.75 \%$ were inundated. Compared to the inundated areas at warning level 1 , the number of those at levels 2 and 3 increased by $13.91 \%\left(5.50 \mathrm{~km}^{2}\right)$ and $25.67 \%\left(10.20 \mathrm{~km}^{2}\right)$, respectively. These areas were flooded with depths from $0.2 \mathrm{~m}$ to more than $3.0 \mathrm{~m}$. Consequently, the study area was categorized into five levels according to inundation depth: (A) $0.2 \mathrm{~m}-0.5 \mathrm{~m}$, (B) $0.5 \mathrm{~m}-1.0 \mathrm{~m}$, (C) $1.0 \mathrm{~m}-2.0 \mathrm{~m}$, (D) $2.0 \mathrm{~m}-3.0 \mathrm{~m}$, and $(\mathrm{E})>3.0 \mathrm{~m}$. The proportion of flooded residential areas that fell into level A decreased remarkably from $21.21 \%\left(8.40 \mathrm{~km}^{2}\right)$ at warning level 1 to $17.12 \%\left(6.78 \mathrm{~km}^{2}\right)$ at warning level 2 , before reaching $7.70 \%\left(3.06 \mathrm{~km}^{2}\right)$ at warning level 3 . In contrast, the areas in level B increased from $10.16 \%\left(4.03 \mathrm{~km}^{2}\right)$ at warning level 1 to $17.51 \%\left(6.93 \mathrm{~km}^{2}\right)$ at warning level 2 , before dropping to $16.46 \%\left(6.51 \mathrm{~km}^{2}\right)$ at warning level 3 . The areas at level $\mathrm{C}$ showed an upward trend and increased dramatically to $35.84 \%\left(14.19 \mathrm{~km}^{2}\right)$ at warning level 3 . These results indicate that most of the unprotected residential areas were flooded to a depth of $1.0 \mathrm{~m}-2.0 \mathrm{~m}$ at warning level 3, which would result in severe damage. This would be further extended at warning level 3, where the proportion of residential areas at inundation depth level D increased to $12.74 \%\left(5.06 \mathrm{~km}^{2}\right)$. In addition, the areas at level E increased more than twofold to $7.01 \%$ $\left(2.78 \mathrm{~km}^{2}\right)$ compared with $3.17 \%\left(1.27 \mathrm{~km}^{2}\right)$ at warning level 2. High-hazard zones with an inundation depth of more than $2 \mathrm{~m}$ (levels D and E) made up 3.57\% (1.43 $\left.\mathrm{km}^{2}\right)$ of the study area at warning level $1,7.12 \%\left(2.85 \mathrm{~km}^{2}\right)$ at warning level 2, and $19.75 \%\left(7.84 \mathrm{~km}^{2}\right)$ at warning level 3. This is a dangerous situation for the residential areas outside the protected area of the Red River dike system in Hanoi and could lead to extensive property damage. 

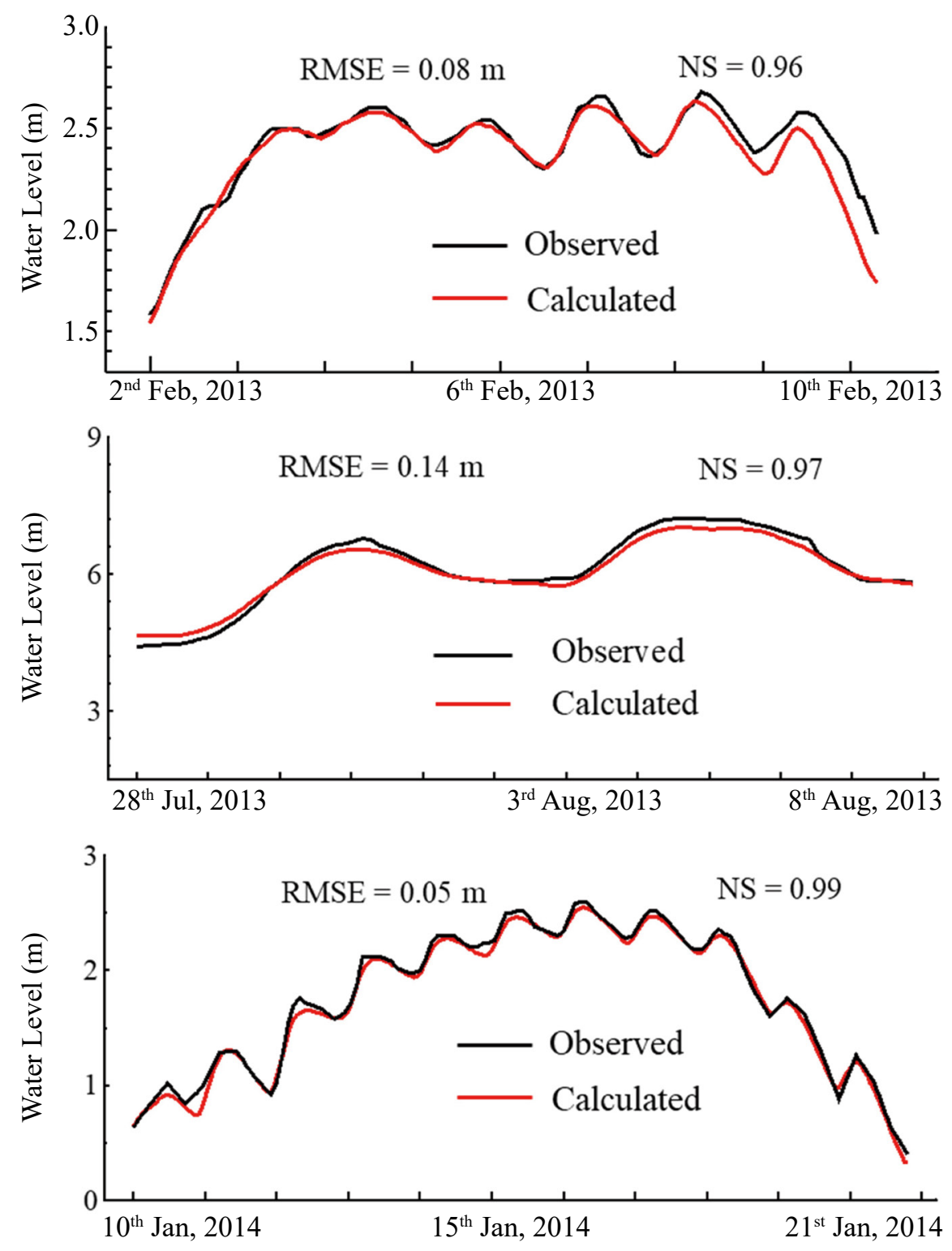

Fig. 3. Calculated and observed water levels at Long Bien for the three validation periods: February 2-10, 2013; July 28-August 8, 2013; and January 10-21, 2014

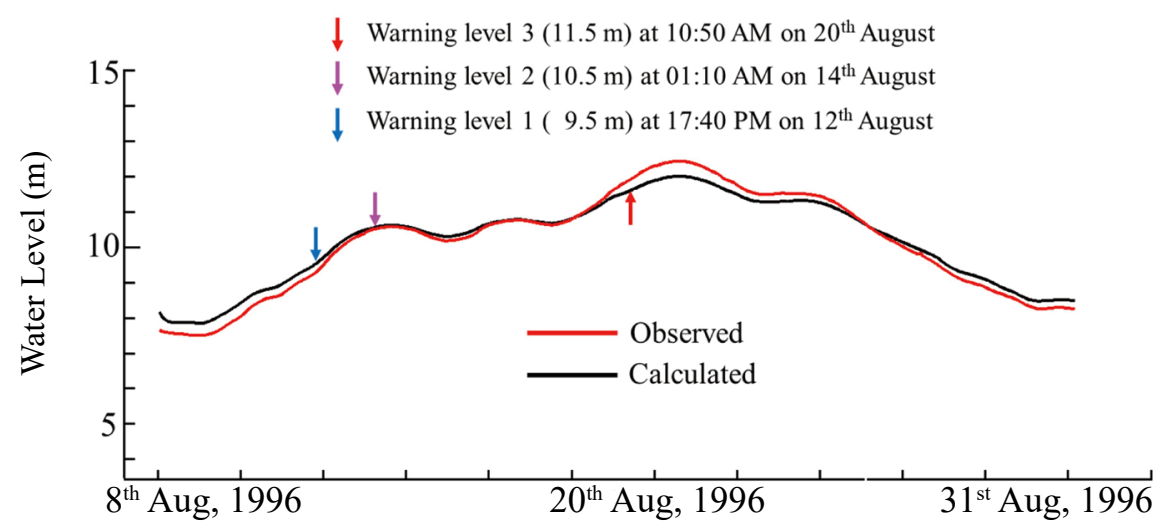

Fig. 4. Calculated and observed water levels at Long Bien for August 8-31, 1996 The colored arrows indicate the time when the calculated water level reached warning levels 1,2 , and 3 . 


\section{Inundated residential areas in each zone at warning level 1}

The study area covered over $110 \mathrm{~km}$ of the Red River from the Son Tay station to Hung Yen station, and was divided into five zones for analysis. Figure 6 shows the inundation depth and Figure 7 presents the flooded residential areas and their proportion of the total residential area in each zone at warning level 1. Zones 1, 2, 3, 4, and 5 comprised residential areas of $10.60 \mathrm{~km}^{2}$, $6.57 \mathrm{~km}^{2}, 9.26 \mathrm{~km}^{2}, 4.96 \mathrm{~km}^{2}$, and $8.20 \mathrm{~km}^{2}$, respectively. In zone $1,44.06 \%\left(4.67 \mathrm{~km}^{2}\right)$ of the area was inundated; inundation depth levels A and B comprised 21.04\% (2.23 $\left.\mathrm{km}^{2}\right)$ and $12.74 \%\left(1.35 \mathrm{~km}^{2}\right)$, respectively. Zone 2 was the safest of the outside residential areas with only $24.65 \%$ $\left(1.62 \mathrm{~km}^{2}\right)$ flooded. The most dangerous inundation depths, levels D and E, accounted for 2.89\% $\left(0.19 \mathrm{~km}^{2}\right)$ and $1.98 \%\left(0.13 \mathrm{~km}^{2}\right)$, respectively. In zone 3, 29.37\% $\left(2.72 \mathrm{~km}^{2}\right)$ of the area was affected. Inundation depth level A made up $15.23 \%\left(1.41 \mathrm{~km}^{2}\right)$ of the zone, and inundation depth level B made up $8.42 \%\left(0.78 \mathrm{~km}^{2}\right)$. Zone 4 is southeast of Hanoi and was more heavily impacted by flooding than zones 1-3. Zone 4 has a total residential area of only $4.96 \mathrm{~km}^{2}$, but $51.61 \%\left(2.56 \mathrm{~km}^{2}\right)$ of that area was flooded. Zone 5 is near Hung Yen station and was strongly affected. Of the total residential area in that zone, $53.30 \%\left(4.37 \mathrm{~km}^{2}\right)$ was inundated. The most dangerous inundation depth, level $\mathrm{E}$, affected an area of only $0.49 \%$.

At warning level 1, the residential areas in each zone mainly experienced inundation depth levels A and B. Most of the high flood hazard areas were in zones 1 and 5 , which are near the riverbank. The results clearly showed that zones 2 and 3 were safer than the other zones, because they are at a higher elevation and farther from the riverbank. Figure 6 shows a high flood hazard area northwest of zone 4 in an area with low elevation. However, most of the residential areas near the riverbank in zones 3 and 4 only experienced depth level A. These results indicated that the residential areas are highly vulnerable to flooding from the river, even at warning level 1.

\section{Inundated residential areas in each zone at warning level 2}

Figures 8 and 9 present the inundation depth levels in each zone at warning level 2. In zone 1, 53.08\% (5.63

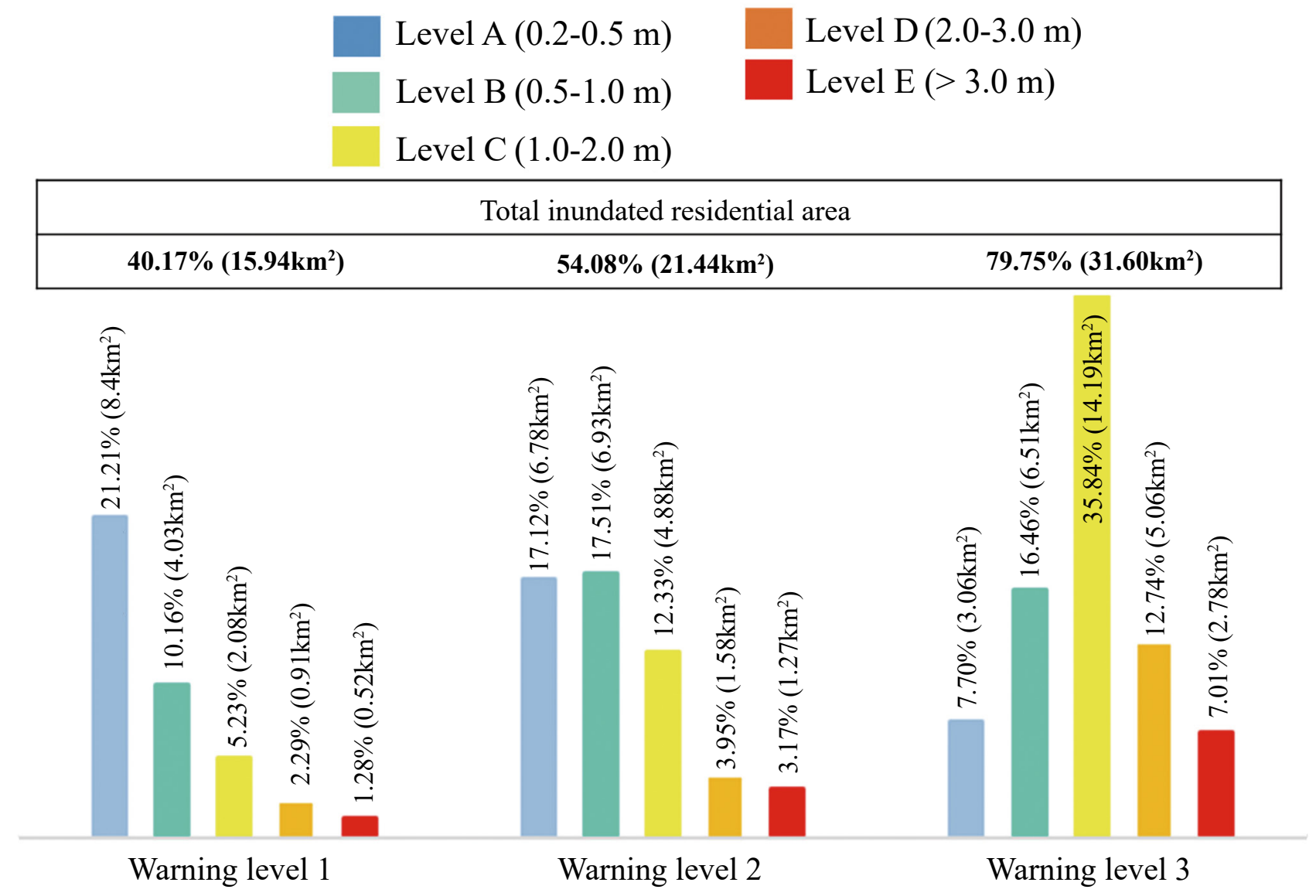

Fig. 5. Inundated residential areas and their percentage of the total residential area for the study area when floodwaters reached warning levels 1-3 at Long Bien 
Flood Hazard Assessment of Residential Areas, Hanoi
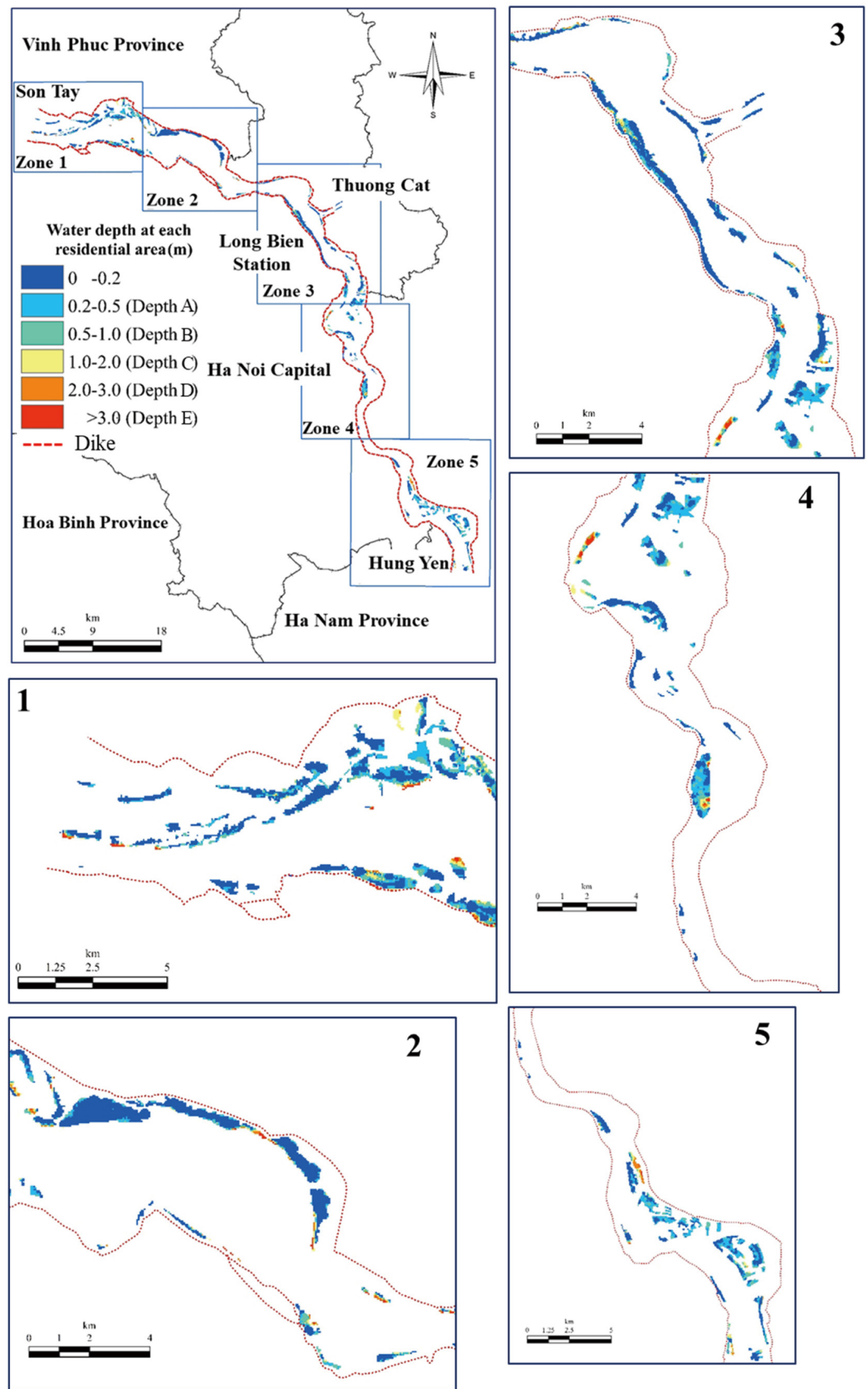

Fig. 6. Inundation depth for each residential area at warning level 1

The river area was erased to highlight the residential areas. 
$\mathrm{km}^{2}$ ) of the residential area was inundated. In zone 2, $33.50 \%\left(2.2 \mathrm{~km}^{2}\right)$ was flooded. Inundation depth levels A, B, C, D, and E made up 9.25\% $\left(0.61 \mathrm{~km}^{2}\right), 7.65 \%(0.50$ $\left.\mathrm{km}^{2}\right), 7.95 \%\left(0.52 \mathrm{~km}^{2}\right), 4.07 \%\left(0.27 \mathrm{~km}^{2}\right)$, and $4.53 \%$ $\left(0.30 \mathrm{~km}^{2}\right)$ of the zone, respectively. In zones 3 and 4 , $44.25 \%\left(4.11 \mathrm{~km}^{2}\right)$ and $68.96 \%\left(3.43 \mathrm{~km}^{2}\right)$ of the total area was inundated, respectively. Zone 5 was the most seriously affected by flooding, with $73.95 \%\left(6.07 \mathrm{~km}^{2}\right)$ of the total area flooded. Inundation depth levels $\mathrm{A}, \mathrm{B}$, and $\mathrm{C}$ made up $25.2 \%\left(2.07 \mathrm{~km}^{2}\right), 25.27 \%\left(2.07 \mathrm{~km}^{2}\right)$, and $15.73 \%\left(1.29 \mathrm{~km}^{2}\right)$ of the zone, respectively. Inundation depth levels D and E combined to make up 7.68\% (0.64 $\mathrm{km}^{2}$ ) of the zone.

Residential areas with a greater flood depth experienced more severe property damage and loss of lives, especially in those households in zones 4 and 5. In zone 4, the residential areas on the east side of the river were significantly affected by flooding, while residential areas on the west side were slightly affected. This can be explained by the topographic differences. Most of the residential areas in zone 5 on the west side the river are near the riverbank, which has a complex topography. Thus, $73.98 \%\left(6.07 \mathrm{~km}^{2}\right)$ of the zone was inundated at warning level 2. In zones 1 and 2, most of the residential areas on the west side of the river experienced inundation depth levels A-C. The residential areas in zone 3 are located on both sides of the river and are fairly balanced. However, those areas southeast of zone 3 were heavily flooded due to their location and low elevation.

\section{Inundated residential areas in each zone at warning level 3}

At warning level 3, most of the residential areas in the study area were inundated. Figures 10 and 11 present the inundation depth levels in each zone. In zones 1 and 2, 78.30\% $\left(8.30 \mathrm{~km}^{2}\right)$ and $55.25 \%\left(3.63 \mathrm{~km}^{2}\right)$ of the

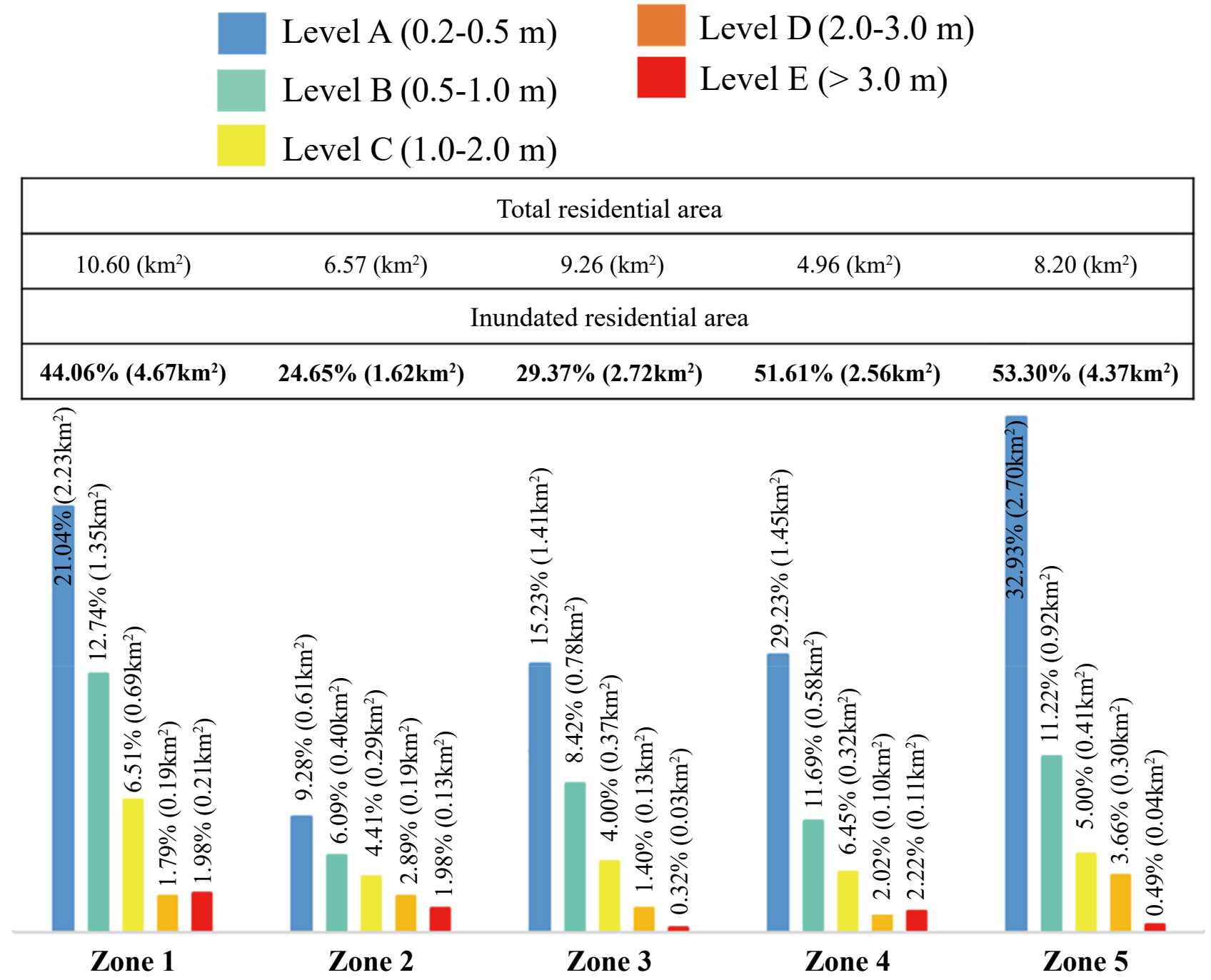

Fig. 7. Inundated residential areas and their percentage of the total residential area in each zone when floodwaters reached warning level 1 at Long Bien 

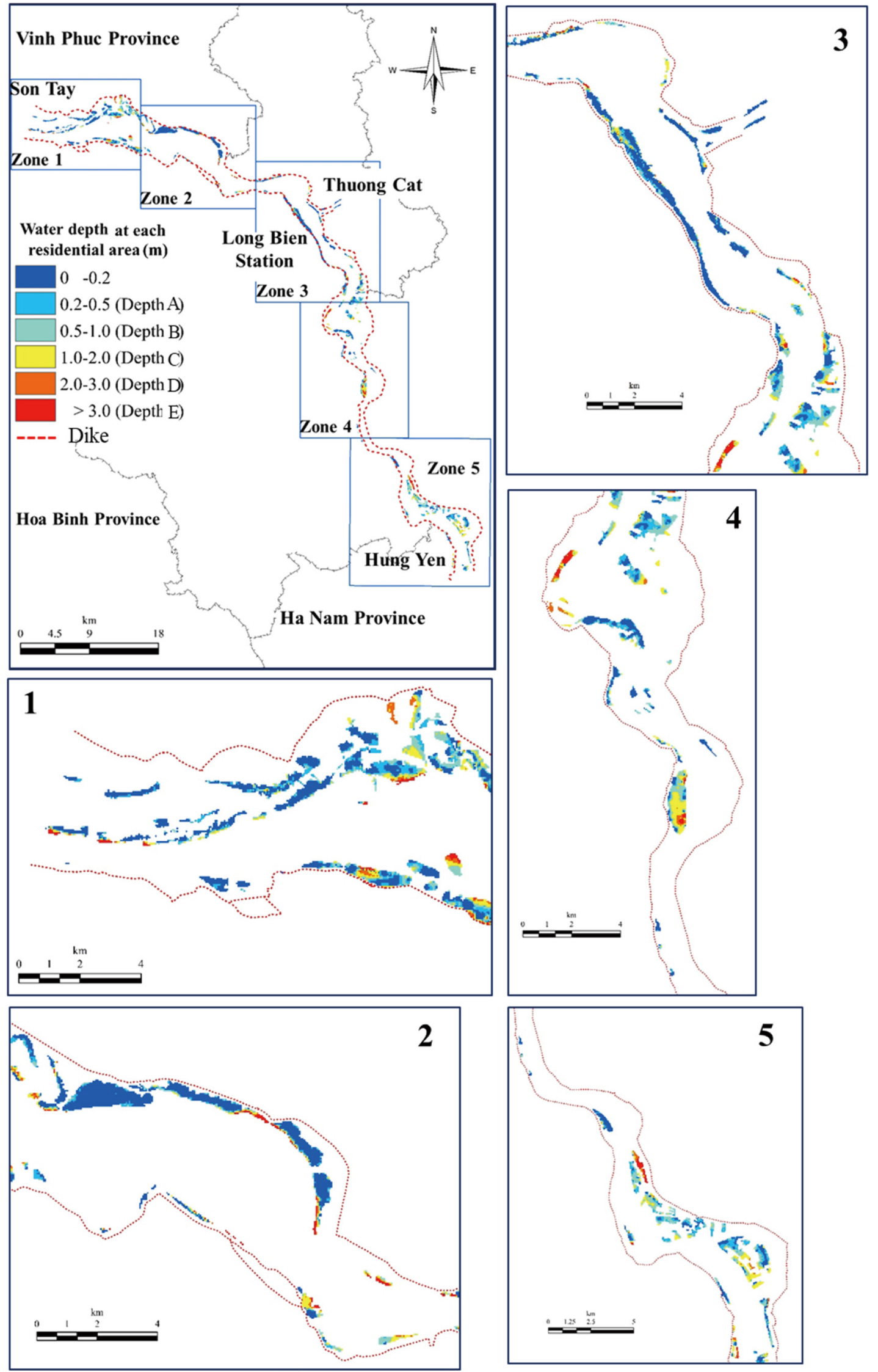

Fig. 8. Inundation depth for each residential area at warning level 2

The river area was erased to highlight the residential areas. 
residential areas were flooded, respectively. In zone 3, inundation depth levels B, C, D, and E made up 17.82\% $\left(1.65 \mathrm{~km}^{2}\right), 33.37 \%\left(3.09 \mathrm{~km}^{2}\right), 9.83 \%\left(0.91 \mathrm{~km}^{2}\right)$, and $3.24 \%\left(0.30 \mathrm{~km}^{2}\right)$ of the zone, respectively. In zone 4 , $97.57 \%\left(4.84 \mathrm{~km}^{2}\right)$ of the total area was inundated. Zone 5 was also mostly flooded at $96.23 \%\left(7.89 \mathrm{~km}^{2}\right)$ of the total area $\left(8.20 \mathrm{~km}^{2}\right)$.

At warning level 3, zones 1, 4, and 5 had the highest proportions of inundated residential areas owing to their low elevation and proximity to the riverbank. Most of the residential areas northwest of zone 1 experienced an inundation depth level of D or E. In zone 4, the residential areas on the east side of the river experienced a level of $D$ or E. In zone 5, most of the residential area on the west side was heavily flooded. Inundation depth level E was mainly observed in zones 2 and 4 at $8.22 \%\left(0.54 \mathrm{~km}^{2}\right)$ and $12.90 \%\left(0.64 \mathrm{~km}^{2}\right)$ of their total areas, respectively. This can be explained by the complexity of the topography. At warning level 3, all zones were mostly at inundation depth level C. However, there were large areas at levels D or E.

\section{Conclusion}

In this study, the flood risk levels for residential areas outside the protected area of the Red River dike system in Hanoi were mapped to enhance flood prevention and mitigation plans. The inundation depth level for the whole study area was comprehensively evaluated at high resolution. A two-dimensional depthaveraged hydrodynamic model was constructed for the simulation. The latest DEM was used for the first time on the study area, which was divided into grid cells with $50 \mathrm{~m}$ resolution.

The results indicate that previous master plans of Hanoi failed to perform a detailed analysis of the vulnerability of the residential areas outside the Red River dike system. This shortcoming should be addressed

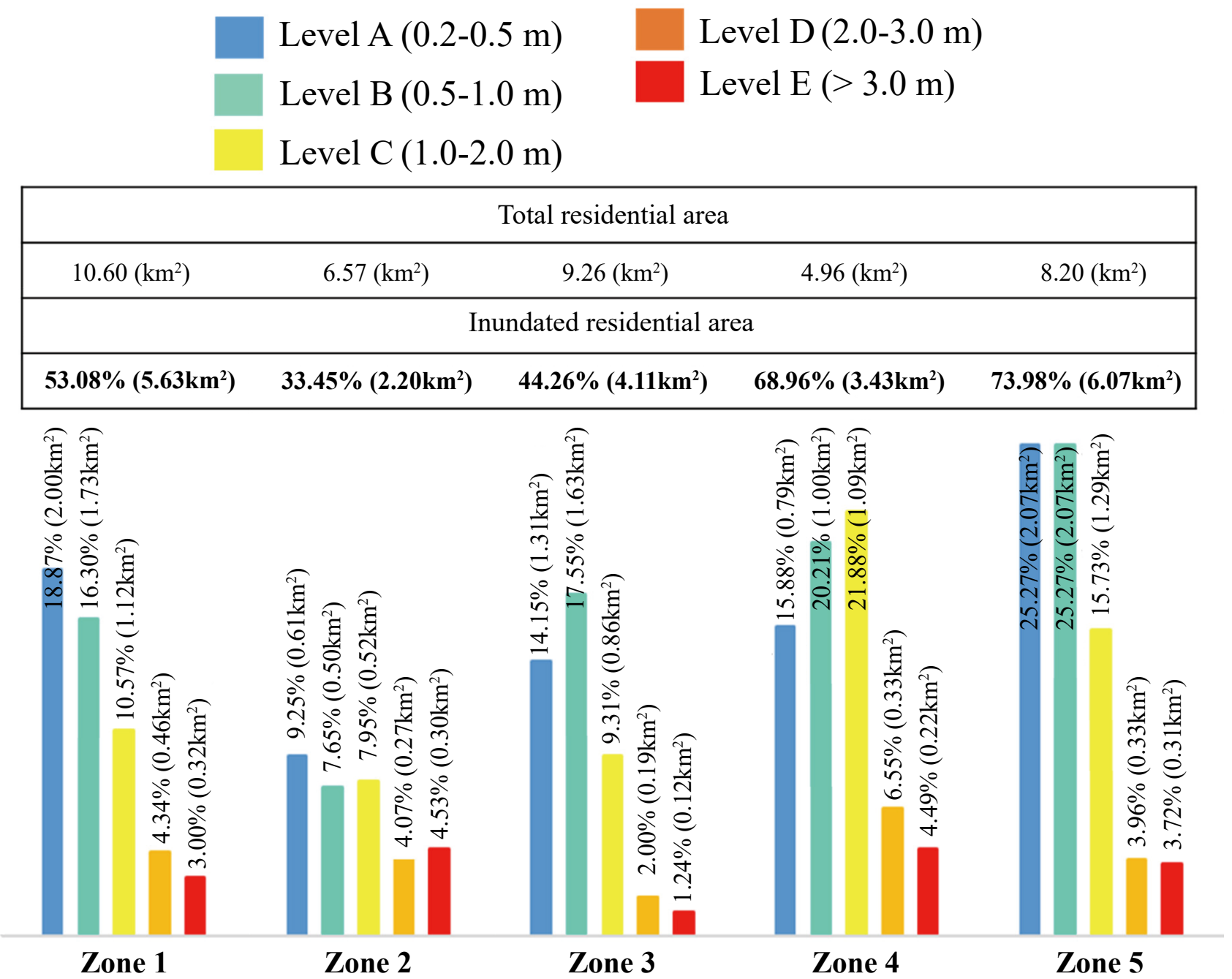

Fig. 9. Inundated residential areas and their percentage of the total residential area in each zone when floodwaters reached warning level 2 at Long Bien 
Flood Hazard Assessment of Residential Areas, Hanoi

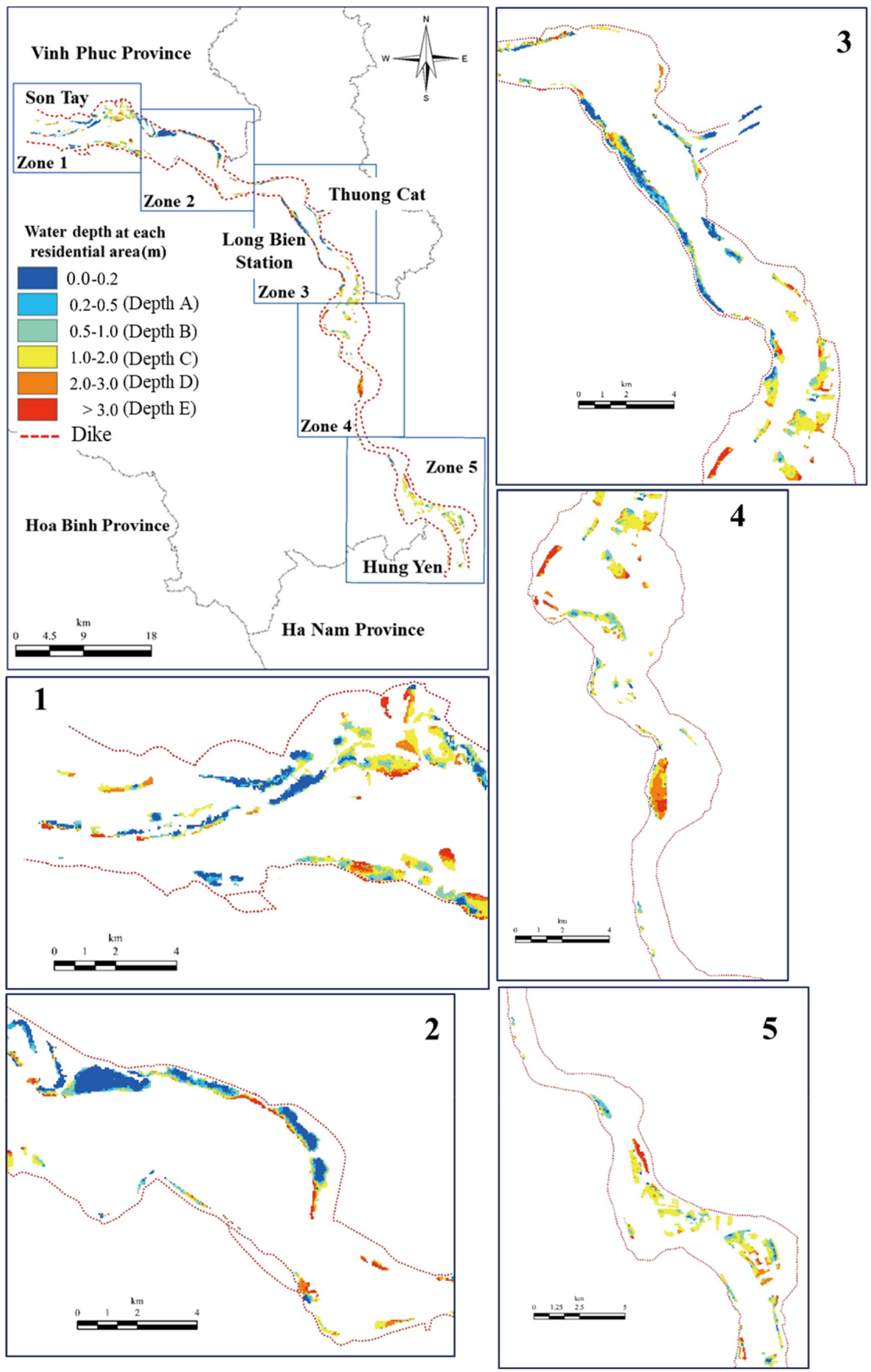

Fig. 10. Inundation depth for each residential area at warning level 3

The river area was erased to highlight the residential areas. 


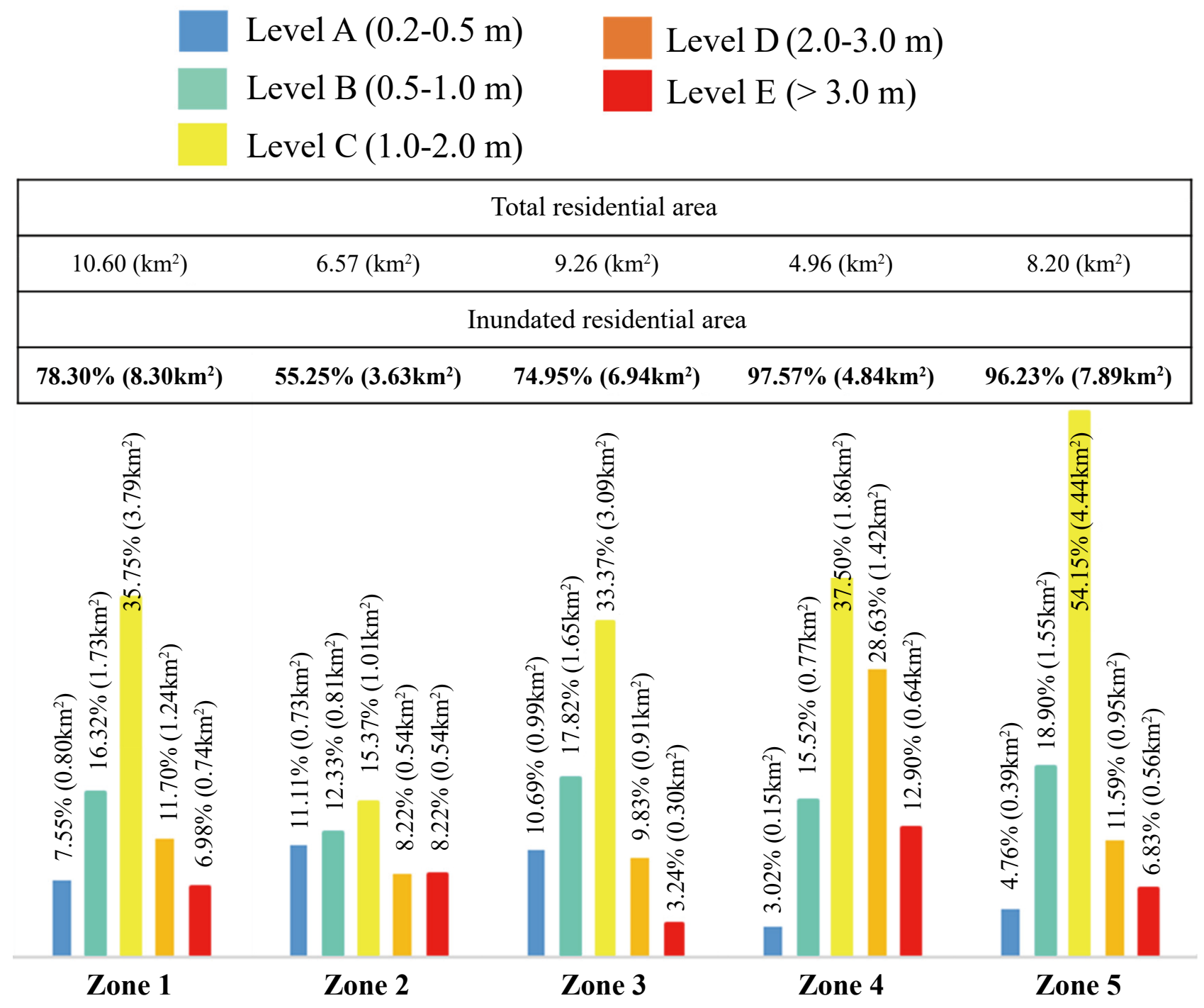

Fig. 11. Inundated residential areas and their percentage of the total residential area in each zone when floodwaters reached warning level 3 at Long Bien

by considering the high-resolution topography, flood characteristics, and inundation depth level for each zone. The output results provide insight on flood hazards for the whole study area and will play a key role in developing an effective flood management strategies for Hanoi.

This study identified a large number of vulnerable residential areas with high inundation depth levels at warning levels 1-3. Even at warning level 1, 40.17\% (15.94 $\mathrm{km}^{2}$ ) of the residential areas were flooded. At warning level 2, 54.08\% $\left(21.44 \mathrm{~km}^{2}\right)$ were inundated, and at warning level 3, 79.75\% $\left(31.60 \mathrm{~km}^{2}\right)$ were also. Zones 4 and 5 were identified as the most vulnerable areas at all warning levels, and flood mitigation activities should begin there. In contrast, zone 2 was the safest in the study area with only $24.65 \%\left(1.62 \mathrm{~km}^{2}\right), 34.45 \%\left(2.20 \mathrm{~km}^{2}\right)$, and $55.25 \%\left(3.63 \mathrm{~km}^{2}\right)$ of the zone affected at warning levels
1, 2, and 3, respectively. Zones 1 and 3 also indicated a high flood risk level. The results of this study suggest that flood forecasting, mitigation, and adaptation strategies should be put at the forefront for the sustainable development of Hanoi, and important construction should be located outside the vulnerable areas. The overall flood prediction shown by the flood risk levels maps is a reliable and useful reference for the development of riskreduction strategies in developing countries like Vietnam.

Based on this study, it is recommended that vulnerable residential areas consider special planning strategies, including other economic and environmental activities. Settlement purposes need to be reevaluated, and people in extremely vulnerable residential areas may need to be relocated. People in residential areas subjected to inundation depth level $\mathrm{E}\left(0.32 \mathrm{~km}^{2}, 0.30 \mathrm{~km}^{2}, 0.12\right.$ 
$\mathrm{km}^{2}, 0.22 \mathrm{~km}^{2}$, and $0.31 \mathrm{~km}^{2}$ in zones $1,2,3,4$, and 5 , respectively) should be relocated, and mitigation strategies for less vulnerable areas should be implemented.

\section{Acknowledgements}

The authors appreciate the funding support of JSPS KAKENHI Grant Numbers JP18H03968 and JP17K15347. The authors also thank Mr. Le Viet Son and Mr. Luong Ngoc Chung of the Institute of Water Resources Planning, Ministry of Agriculture and Rural Development, Vietnam, for providing the topographic data and observed profiles of the Red River.

\section{References}

Bates, P.D. et al. (1999) Two dimensional finite element modelling of floodplain flow, La Houille Blanche, 3-4, 82-88.

Bellos, V. \& Tsakiris, G. (2015) Comparing various methods of building representation for 2D flood modelling in built-up areas, Water Resour. Manag., 29, 379-397.

Bricker, J. D. et al. (2015) On the Need for Larger Manning's Roughness Coefficients in Depth-Integrated Tsunami Inundation Models. Coast Eng J., 57, 1-13. https://doi.org/ $10.1142 / \mathrm{S} 0578563415500059$

Brunner, G. (2010) HEC River Analysis System (HEC-RAS) Version 4.1

Chaieb, A. et al. (2016) Vertical Accuracy Assessment of SRTM Ver 4.1 and ASTER GDEM Ver 2 Using GPS Measurements in Central West of Tunisia. Journal of Geographic Information System., 8, 57-64. https://doi.org/ 10.4236/jgis.2016.81006.

Chen, H. et al. (2018) Hydraulic correction method (HCM) to enhance the efficiency of SRTM DEM in flood modeling. J. Hydrol., 559, 56-70. https://doi.org/10.1016/j.jhydrol. 2018.01.056.

Chen, W. et al. (2019) Integrated urban flood vulnerability assessment using local spatial dependence-based probabilistic approach, J. Hydrol., 575, 454-469. https://doi. org/10.1016/j.jhydrol.2019.05.043.

Darabi, H. et al. (2019) Urban flood risk mapping using the GARP and QUEST models : A comparative study of machine learning techniques. J. Hydrol., 569, 142-154. https://doi.org/10.1016/j.jhydrol.2018.12.002.

Degiorgis, M. et al. (2012) Classifiers for the detection of floodprone areas using remote sensed elevation data, J. Hydrol., 470-471, 302-315. https://doi.org/10.1016/j.jhydrol. 2012.09.006.

Domeneghetti, A. et al. (2015) Evolution of flood risk over large areas: Quantitative assessment for the Po river, J. Hydrol., 527, 809-823. https://doi.org/10.1016/j.jhydrol. 2015.05.043.

Dutta, D. et al. (2007) A two-dimensional hydrodynamic model for flood inundation simulation: A case study in the lower Mekong river basin, Hydrol. Process., 21, 1223-1237.

Gerritsen, H. (2005) What happened in 1953? The big flood in the Netherlands in retrospect, Philos. Trans. A. Math.
Phys. Eng. Sci., 363, 1271-1291. https://doi.org/10.1098/rsta. 2005.1568.

Gharbi, M. et al. (2016) Floods effects on rivers morphological changes application to the Medjerda River in Tunisia, J. Hydrol. Hydromech., 64, 56-66.

Government of Vietnam, National report on disaster reduction in Vietnam, In Proceedings of the World Conference on Disaster Reduction, Geneva: UNISDR, 2005. Available at: https://www.unisdr.org/2005/mdgs-drr/national-reports/ Vietnam-report.pdf.

Haile, S. et al. (2018) Regional studies flood hazard mapping using FLO-2D and local management strategies of Dire Dawa city, Ethiopia, J. Hydrol. Reg. Stud., 19, 224-239. https://doi.org/10.1016/j.ejrh.2018.09.005.

Hajat, S. et al. (2005) The human health consequences of flooding in Europe: A review. In Extreme Weather Events and Public Health Responses, Berlin: Springer, pp. 185-196. https://doi.org/10.1007/3-540-28862-7 18.

Kirsch, T.D. et al. (2012) Impact of the 2010 Pakistan floods on rural and urban populations at six months, PLoS Curr., 1 , 1-9. https://doi.org/10.1371/4fdfb212d2432.

Komi, K. et al. (2017) Modelling of flood hazard extent in data sparse areas: a case study of the Oti River basin, West Africa. J. Hydrol. Regional Studies, 10, 122-132. https:// doi.org/10.1016/j.ejrh.2017.03.001.

Li, W. et al. (2019) Risk assessment and sensitivity analysis of flash floods in ungauged basins using coupled hydrologic and hydrodynamic models, J. Hydrol., 572, 108-120. https:// doi.org/10.1016/j.jhydrol.2019.03.002.

Manfreda, S. et al. (2014) Investigation on the use of geomorphic approaches for the delineation of flood prone areas, J. Hydrol., 517, 863-876. https://doi.org/10.1016/j. jhydrol.2014.06.009.

Ministry of Natural Resources and Environment (MONRE) (2012) Climate Change, Sea Level Rise Scenarios for Vietnam. Hanoi: Vietnam Publishing House of Natural Resources, Environment and Cartography. Available at: http://www.imh.ac.vn/files/doc/KichbanBDKH/ KBBDKH final May 2012_Part1.pdf (Accessed 5 August 2019) [In Vietnamese].

Natural Disaster Risk Assessment and Area Business Continuity Plan Formulation for Industrial Agglomerated Areas in the ASEAN Region - Country Report - Vietnam, (2015) JICA, Tokyo.

Neal, J. et al. (2012) A subgrid channel model for simulating river hydraulics and floodplain inundation over large and data sparse areas. Water Resour. Res., 48, 1-16. https://doi. org/10.1029/2012WR012514.

NOAA's Top Global Weather, Water and Climate Events of the $20^{\text {th }}$ Century (1993) Silver Spring, MD: NOAA.

Rexer, M. \& Hirt, C. (2014) Comparison of free high resolution digital elevation data sets (ASTER GDEM2, SRTM v2.1/ v4.1) and validation against accurate heights from the Australian National Gravity Database. Aust. J. Earth Sci., 61, 213-226. https://doi.org/10.1080/08120099.2014.884983.

Royal Thai Government and the World Bank (2012) Thailand Flooding 2554 Rapid Assessment for Resilient Recovery and Reconstruction Planning 18, UNDP, New York.

Saksena, S. et al. (2019) Flood inundation modeling and mapping by integrating surface and subsurface hydrology with river hydrodynamics, J. Hydrol., 575, 1155-1177. 
https://doi.org/10.1016/j.jhydrol.2019.06.024.

Sampson, C.C. et al. (2015) A high-resolution global flood hazard model, Water Resour. Res., 51, 7358-7381. https:// 10.1002/2015WR016954.

Shadmehri, T.A. et al. (2019) River basin-scale flood hazard assessment using a modified multi-criteria decision analysis approach: A case study, J. Hydrol., 574, 660-671. https://doi.org/10.1016/j.jhydrol.2019.04.072.

Smagorinsky, J. (1963) General circulation experiments with the primitive equations, Mon. Weather Rev., 91, 99.
Tanoue, M. et al. (2016) Global-scale river flood vulnerability in the last 50 years, Sci. Rep. 6, article no. 36021. https:// doi.org/10.1038/srep36021.

Uchiyama, Y. (2004) Modeling Wetting and Drying Scheme Based on an Extended Logarithmic Law for a ThreeDimensional Sigma-Coordinate Coastal Ocean Model, Yokosuka: Port and Airport Research Institute.

Wilson, M. D. et al. (2007) Modeling large-scale inundation of Amazonian seasonally flooded wetlands. Geophys. Res. Lett., 34, 4-9. https://doi.org/10.1029/2007GL030156. 